\title{
Long-Term Determinants of the Size of the Non-Profit Sector Serving Households in the Visegrad Countries ${ }^{1}$
}

\author{
Jindrich Spicka, Marketa Arltova, Petr Boukal, Lubos Smrcka
}

\author{
University of Economics, Prague \\ nam. W. Churchilla 4, 13067 Prague 3, Czech Republic \\ E-mail.jindrich.spicka@vse.cz,marketa.arltova@vse.cz,petr.boukal@vse.cz,lubos.smrcka@vse.cz \\ cross $^{\text {ref }}$ http://dx.doi.org/10.5755/j01.ee.28.5.19254
}

\begin{abstract}
Non-profit sector plays essential role in economies despite its marginal share in GDP since it provides valuable services for needy social groups. The article investigates differences in socioeconomic determinants of the size of the non-profit sector serving households in the Visegrad Countries particularly as to the magnitude and direction of the effect that these determinants exert. Getting knowledge about significant determinants of non-profit sector is important both for policy makers and the founders of non-profit organizations in their strategic decision making. The results are based on panel data regression in the long-term period 2000-2014. The Visegrad Group was investigated because it is a cultural and political alliance of four Central European states. Selected indicators represent supply-and demand-side theory of non-profit sustainability. The results show that GDP per capita is the significant determinant of the non-profit sector in the country with no tax assignation. The different systems of care for the elderly have an impact on the determinants of the size of the non-profit sector serving households (old-age dependency ratio, life expectation index). The government failure theory was established only in the Czech Republic where obvious competition between non-profit sector and health care system exists. In most Visegrad countries non-profit organizations help governmental sector to cope with increasing number of refugees in need, which supports the interdependence theory.
\end{abstract}

Keywords: Central European Countries, Non-Profit Sector Serving Households, Econometric Modelling, Government Failure Theory, Immigration.

\section{Introduction}

Non-profit organizations are an integral part of the economy of developed as well as developing countries. They are the important service provider based on contracting with local government. In Central Europe, local governments give grants to non-governmental organizations (NGOs) for this purpose (Struyk, 2002). The development of the non-profit sector in Central Europe was specific because of the socioeconomic changes at the turn of 1980s and 1990s. The specific features of the Central European non-profit sector obviously result from the extent to which the Communist legacy shaped the composition of the NGO sector in economic terms. The post-communist NGOs remain influenced by the region's communist past (Potucek, 2000).

The relative size of the Central European non-profit sector has been smaller compared to the welfare states in the Western Europe and the North America. For example, education, health and social services make up less than 40 percent of NGO employment in Central Europe, these three fields account on average for nearly 80 percent in the developed countries of Western Europe and other developed countries (Toepler \& Salamon, 2003). Toepler and Salamon suggest that "these significant differences very likely reflect the chronic shortage of resources available to NGOs in
Central Europe to engage in the provision of highly complex and potentially capital-intensive welfare service delivery, but also the greater willingness of Eastern and Central Europeans in general to continue to rely on the state to provide these services" (Toepler \& Salamon, 2003, p. 370).

The specific issue of the non-profit sector is its revenue structure. Besides the conventional funding sources of NGOs, like donations, endowments (private and corporate), membership fees, and business activities, there are further ways for financial support in Central Europe. There are specialized foundations for financing NGOs with initial capital, tax concessions for business activities related to the goals of the organizations, a " $1 \%$ " mechanism, where taxpayers have the right to determine the receiver, or reduction of the tax paid by them - as well as lotteries (Mccarthy \& Knabe, 2012). The Central European revenue structure of non-profit organizations is different from other regions. The non-profits receive the bulk of their revenue not from private philanthropy or the government, but from private fees and charges. Moreover, the earned income has been significant source of Central and Eastern European NGOs' income (Toepler \& Salamon, 2003). In the Visegrad Group, there are significant regional differences with comparatively higher share of public sector support in the Czech Republic because of the ongoing state support system

\footnotetext{
${ }^{1}$ This work was supported by the institutional support for long-term conceptual development of the research organization University of Economics, Prague (project Best practice in non-governmental organizations, VŠE IP309067) and by the Czech Science Foundation Project No. P402/12/G097 DYME - Dynamic Models in Economics.
} 
for social organizations after the "velvet revolution". The regional differences might affect the size of the non-profit sector serving households and its determinants.

The determinants of the size of the non-profit sector serving households closely relate to the demand-side and supply-side theory of non-profit sustainability. A recent empirical study of rural non-profit sector in the Czech Republic (Valentinov \& Vacekova, 2015) shows that it is sometimes not possible to clearly classify the demand-side and the supply-side sustainability determinants. Rather, there is a controversial entanglement of demand-side and supply-side identities. Demand and supply factors operate simultaneously and it is difficult to separate them. There are relations between supply and demand theory in the nonprofit sector, however, none of them explain the reasons for the considerable structural heterogeneity of entities in the non-profit sector (Valentinov, 2008). Recent studies replaced the demand-side and supply-side theories by the stakeholder approach which offers more integrative framework for understanding variations in non-profit sector density (van Puyvelde \& Brown, 2016).

The supply of non-profit organizations is determined by the volume of funding sources (Gronbjerg \& Paarlberg, 2001) and, for instance, by the efforts of the non-profit organizations to promote particular opinion, typical for religious non-profits. Luksetich (Luksetich, 2008) empirically validated the conclusions of former publications that the availability of government grant programs is a very important determinant of the size of the non-profit sector. However, the author pointed out that not all non-profit institutions have the same funding structure. Some nonprofits, e.g. social care organizations or hospitals, are strongly dependent on financial contributions from public resources or grant programs; other non-profit institutions are more self-sufficient and are partly funded from their own economic activity. Thus, the relation between government grant programs and the number of non-profit institutions cannot be applied generally to the entire non-profit sector.

Funding resources also positively depend on the relative welfare of the country as expressed by Gross Domestic Product(GDP) per capita (Pevcin, 2012). Private donors can be partly displaced by public endowments (O'Regan and Oster, 2002). However, no full displacement effect was proved because the public deems some services provided by non-profit institutions to be unique and irreplaceable by any governmental activities (Weinblatt, 1992).

Disposable sources also include volunteers, who are willing to make considerable working efforts to accomplish the mission of a non-profit. The volunteer rates depend on socio-demographic variables and contextual data, such as government expenditures on social issues and GDP (GilLacruz \& Marcuello, 2013).

The theory of demand for services provided by the non-profit sector is associated with the market failure theory and government failure. The government failure theory is based on the importance of the non-profit sector as a substitute for the missing social services offered by the government. Based on econometric modelling of empirical data, the government failure can be illustrated by the negative dependence between the government expenditure on education and health and the size of the non-profit sector without volunteers (Matsunaga et al., 2010). Thus, the competition between the services provided by the government and by the NGOs (Schmid, 2004; Salamon \& Toepler, 2015; van Puyvelde \& Brown, 2016), should be particularly obvious in the Central European region. Recent study (Bae \& Sohn, 2017) supported the government failure theory based on the county-level longitudinal data in the USA. Liu (2017) revisited government failure theory by examining the relationship between government decentralization and the size of the non-profit sector. Counties with a more horizontally fragmented governmental system are associated with a larger size of the non-profit sector. However, government failure theory was only partially supported.

Apart from the government failure theory, there is also a theory of interdependence, i.e. mutual interconnection (Lecy \& van Slyke, 2013). The non-profit services are neither a substitute nor a competitor to the governmental activities or public sector activities; they are rather their complement based on partnership and cooperation (Gazley, 2010). Bae and Sohn (2017) have recently confirmed interdependence theory since random effects models showed that federal funding and local funding are positively associated with the size of non-profit sectors. Moreover, interdependence theory was also recently supported by Liu (2017).

In this article we investigate non-profit sector serving households. Despite definition of non-profit sector serving households does not cover all non-profit organizations, the NPISHs represents bulk of the non-profit organizations. The document "European System of Accounts ESA 2010" (European Commission, 2013) contains a definition of nonprofit institutions serving households and content of final consumption expenditure of non-profit institutions serving households. "The non-profit institutions serving households (NPISHs) sector (S.15) consists of non-profit institutions which are separate legal entities, which serve households and which are private non-market producers. Their principal resources are voluntary contributions in cash or in kind from households in their capacity as consumers, from payments made by general government and from property income. The NPISHs sector includes the following main kinds of NPISHs that provide non-market goods and services to households:

- trade unions, professional or learned societies, consumers' associations, political parties, churches or religious societies (including those financed but not controlled by governments), and social, cultural, recreational and sports clubs; and

- charities, relief and aid organizations financed by voluntary transfers in cash or in kind from other institutional units.

Sector S.15 includes charities, relief or aid agencies serving non-resident units and excludes entities where membership gives a right to a predetermined set of goods and services."

In this paper, we report on significant long-term determinants of the size of the non-profit sector serving households in four post-communist countries (Visegrad Group). This is important because non-profit sector remains influenced by the region's communist past, but it has significantly increased its size recently. Non-profit sector has great importance despite its relatively marginal share in 
GDP. All four Visegrad countries experienced similar historical development in the 20th century including the transformation from Communist era to representative democracy. However, due to differences in culture, public support of the non-profit sector, and income levels, the socioeconomic characteristics considered by this study may play a different role in determination of the size of the sector in each of the countries. Moreover, getting knowledge about significant determinants of the non-profit sector is important both for policy makers and founders of non-profit organizations in their strategic decision making. This is the main reason why we investigated it through quantitative research, namely panel data regression modelling.

\section{Research Questions}

The article extends findings from the empirical studies (Pryor, 2012; Pevcin, 2012) of view on the Central European Region, especially the Visegrad countries - the Czech Republic, Hungary, Poland and Slovakia. Despite all four countries experienced similar historical development in the $20^{\text {th }}$ century, including the transformation from Communist era to representative democracy, the cultural differences, distinct public support of the non-profit sector and income level of the country could give rise to different power and direction of socioeconomic determinants of the size of the non-profit sector serving households.

The article answers the question which macroeconomic and social indicators significantly affect the size of the nonprofit sector serving households in the Visegrad countries? The aim of the article is to identify the determinants of the size of the non-profit sector serving households, and to determine the direction and intensity of their influence on the size of the non-profit sector serving households in Visegrad countries. The results are discussed. We also discuss limits of the research in the conclusion.

The research questions follow theoretical and empirical findings by recently published studies which do not separate demand and supply side theory of non-profit sustainability. This article measures impact of supply-side and demandside indicators on the non-profit sector size simultaneously in one model for each of the countries. Furthermore, the article attempts to verify government failure theory and interdependence theory which were discussed in the literature review.

\section{Selection of Variables}

The determinants of the size of the non-profit sector serving households are tested through the dependency between Final consumption expenditure of non-profit institutions serving households per capita (NGO) and explanatory socioeconomic indicators.

The proxy for the size of the non-profit sector is the response variable "Final consumption expenditure of nonprofit institutions serving households per capita" (NGO) in constant prices (2010) and purchasing power parity.

"Final consumption expenditure of NPISHs includes two separate categories: a) the value of the goods and services produced by NPISHs other than own-account capital formation and other than expenditure made by households and other units; b) expenditures by NPISHs on goods or services produced by market producers that are supplied - without any transformation - to households for their consumption as social transfers in kind" (EC, 2013).

A group of explanatory variables was selected based on supply-side and demand-side theories of the non-profit sector.

The supply-side theory of non-profit sustainability is represented by two explanatory variables.

- GDP: The Gross domestic product per capita (GDP) reflects the economic level of the country. The previous research (Pryor, 2012; Pevcin, 2012) has shown that GDP significantly positively affects the size of the non-profit sector. GDP is expressed in US dollars per capita in purchasing power parity, and at constant prices of 2010 .

- $E D U C(\%)$ : The share of population with tertiary education relative to total population in the country. It represents the level of education in the country. The hypothesis is that the higher the education level of the population, the greater the altruistic behaviour of the society as well as a dimension of non-profit organizations in the country.

The demand-side theory of non-profit sustainability depicts the need for services of the non-profit organizations serving households which provide a variety of social services such as housing, health care, culture, education, social care, social protection and faith involvement. So, authors identified following representatives of the variables.

- AGE (\%): The Old-age dependency ratio, expressed as a proportion of people aged $65+$ to the population aged 15-64. The hypothesis is that the higher the proportion of elderly people in the economically active population, the greater a burden on the country's social system. Thus, it gives more space to the non-profit organizations.

- HEALTH: The Government expenditures on health care per capita, expressed in US dollars per capita in purchasing power parity, and at constant prices of 2010. The hypothesis is that the lower the government spending on health care, the greater the need for NGOs to cast that role of the government (government failure theory). However, since the non-profit organizations serving households have been supported by payments made by general government, there could be a positive relationship where the government supports both health care and social care in the NGOs.

- LIFEEXP: Life expectancy at birth refers to the average number of years a new-born is expected to live if mortality patterns at the time of its birth remain constant in the future. The hypothesis is that increasing life expectancy goes hand in hand with improving living and economic conditions of the elderly which is supported by the development of the non-profit sector.

- REFUG: The number of refugees per hundred thousand inhabitants. The hypothesis is that the higher is a relative number of refugees in the country, the greater is the need for social services provided through NGOs. This issue has been more topical in recent years. 
Jindrich Spicka, Marketa Arltova, Petr Boukal, Lubos Smrcka. Long-Term Determinants of the Size of the Non-Profit...

- $\operatorname{UNEMPL}(\%)$ : The annual unemployment rate of the population between 15 and 64 years old. The hypothesis is that the higher the unemployment, the greater the demand for the social services of the non-profit sector.

The dataset contains annual time series data in the period 2000-2014. The data comes from the official databases of the Organization for Economic Co-operation and Development (NGO, AGE, EDUC, GDP, HEALTH, UNEMPL; OECD, 2016), the World Health Organization (LIFEEXP; WHO, 2016) and the World Bank (REFUG; WB, 2016).

Table 1 contains the summary statistics of the indicator in the Visegrad Group - the Czech Republic, Hungary, Poland and Slovakia.

The Czech Republic can be characterized by relatively low and stable size of the non-profit sector serving households, the highest mean GDP per capita, the highest government health expenditures per capita, the highest life expectancy at birth and the lowest unemployment rate in the Visegrad Group. The Czech Republic seems to have stable and favourable economic development. Moreover, the nonprofit sector is a stable partner of the state. Like in other countries, the partnership between state and NGOs has been influenced by the political environment. Under the rightwing government, the social policy is usually eclipsed. On the contrary, the left-wing government usually places greater emphasis on the non-profit sector.

The Slovak Republic takes the second place in the mean GDP per capita, it has the most favorable age structure but the lowest share of population with tertiary education, like the Czech Republic. From the social point of view, there is the highest unemployment rate but the lowest number of refugees per hundred thousand inhabitants. However, there are difficult relationships between state and NGOs in the Slovak Republic. So, the process of the standard governmentthird sector relationship development has been delayed since NGOs have felt frustrated from their non-acceptance by the state as a development actor (Strecansky, 2012).

Hungary has the highest relative size of the non-profit sector serving households. This fact suggests that the service-providing role of NGOs has recently deserved far more attention than it attracted in the first years of the transition period in 1990s. There is the worst age structure of population, measured through the old-age dependency ratio, and the highest number of refugees per hundred thousand inhabitants in Hungary which has an impact on the size of the non-profit sector serving households.

Poland has the lowest relative size of the non-profit sector serving households. It has the lowest GDP per capita and, consequently, the lowest government health expenditures per capita in the Visegrad group.

Table 1

Summary Statistics (2000-2014)

\begin{tabular}{|c|c|c|c|c|c|c|c|c|}
\hline & NGO & GDP & AGE & EDUC & HEALTH & LIFEEXP & REFUG & UNEMPL \\
\hline \multicolumn{9}{|c|}{ Czech Republic } \\
\hline Mean & 168.64 & 25134.04 & 21.21 & 15.77 & 1456.41 & 76.63 & 19.63 & 7.11 \\
\hline Median & 183.98 & 26419.21 & 20.30 & 14.40 & 1459.35 & 76.80 & 19.86 & 7.19 \\
\hline Max & 201.47 & 27927.97 & 25.70 & 22.20 & 1671.01 & 78.60 & 30.28 & 8.83 \\
\hline Min & 124.09 & 20191.11 & 19.70 & 11.80 & 1080.96 & 74.70 & 11.22 & 4.44 \\
\hline S.D. & 28.11 & 2831.00 & 1.96 & 3.50 & 197.53 & 1.25 & 6.41 & 1.14 \\
\hline \multicolumn{9}{|c|}{ Slovak Republic } \\
\hline Mean & 215.45 & 21539.38 & 17.03 & 15.61 & 1149.86 & 74.62 & 8.63 & 14.95 \\
\hline Median & 229.35 & 23291.13 & 16.70 & 15.20 & 1186.72 & 74.40 & 8.25 & 14.26 \\
\hline $\operatorname{Max}$ & 257.81 & 26616.43 & 19.00 & 20.90 & 1508.65 & 76.40 & 14.75 & 19.33 \\
\hline Min & 137.67 & 15215.21 & 16.30 & 10.60 & 736.61 & 73.00 & 4.62 & 9.60 \\
\hline S.D. & 45.44 & 4063.28 & 0.83 & 3.58 & 277.22 & 1.03 & 2.85 & 3.01 \\
\hline \multicolumn{9}{|c|}{ Hungary } \\
\hline Mean & 327.21 & 21110.60 & 23.59 & 20.95 & 1094.09 & 73.69 & 58.58 & 8.11 \\
\hline Median & 334.00 & 21632.44 & 23.33 & 20.70 & 1101.89 & 73.50 & 59.83 & 7.54 \\
\hline Max & 366.05 & 23290.35 & 26.14 & 25.30 & 1269.89 & 75.60 & 80.78 & 11.25 \\
\hline Min & 258.60 & 17315.34 & 22.09 & 16.20 & 865.78 & 71.70 & 24.62 & 5.73 \\
\hline S.D. & 31.10 & 1830.09 & 1.24 & 3.12 & 113.55 & 1.23 & 18.57 & 2.08 \\
\hline \multicolumn{9}{|c|}{ Poland } \\
\hline Mean & 150.15 & 18419.94 & 19.05 & 21.37 & 838.37 & 75.53 & 24.03 & 13.40 \\
\hline Median & 156.37 & 18771.05 & 18.90 & 21.50 & 832.24 & 75.30 & 26.37 & 10.46 \\
\hline $\operatorname{Max}$ & 211.00 & 23070.84 & 21.42 & 31.00 & 1050.50 & 77.30 & 43.19 & 20.28 \\
\hline Min & 93.04 & 14135.15 & 17.90 & 12.30 & 545.05 & 73.70 & 2.67 & 7.20 \\
\hline S.D. & 42.40 & 3167.63 & 0.91 & 6.25 & 186.79 & 1.10 & 17.05 & 4.82 \\
\hline
\end{tabular}

Source: data OECD, WHO and World Bank, own calculations

Unit Root Test of the Time Series and of the First Differences

Table 2

\begin{tabular}{|c|c|c|c|c|c|c|c|c|}
\hline & \multicolumn{2}{|c|}{$y_{t}$} & \multicolumn{2}{|c|}{$\Delta y_{t}$} & \multicolumn{2}{|c|}{$y_{t}$} & \multicolumn{2}{|c|}{$\Delta y_{t}$} \\
\hline & $t_{A D F}$. & Prob. & $t_{A D F}$ & Prob. & $t_{A D F}$. & Prob. & $t_{A D F}$. & Prob. \\
\hline & \multicolumn{4}{|c|}{ Czech Republic } & \multicolumn{4}{|c|}{ Slovak Republic } \\
\hline NGO & 0.9274 & 0.8936 & -3.2544 & 0.0470 & -2.3174 & 0.1810 & -3.6133 & 0.0304 \\
\hline GDP & 2.3058 & 0.9909 & -1.8774 & 0.0439 & 3.2895 & 0.9987 & -3.0155 & 0.0496 \\
\hline AGE & 4.7079 & 0.9998 & -3.8254 & 0.0010 & 5.6992 & 1.0000 & -3.2119 & 0.0472 \\
\hline EDUC & 8.6455 & 1.0000 & -3.8743 & 0.0011 & -3.5100 & 0.0845 & -4.9539 & 0.0040 \\
\hline
\end{tabular}


Inzinerine Ekonomika-Engineering Economics, 2017, 28(5), 524-534

\begin{tabular}{|c|c|c|c|c|c|c|c|c|}
\hline & \multicolumn{2}{|c|}{$y_{t}$} & \multicolumn{2}{|c|}{$\Delta y$} & \multicolumn{2}{|c|}{$y_{t}$} & \multicolumn{2}{|c|}{$\Delta y_{t}$} \\
\hline & $t_{A D F}$. & Prob. & $t_{A D F}$ & Prob. & $t_{A D F}$. & Prob. & $t_{A D F}$. & Prob. \\
\hline & \multicolumn{4}{|c|}{ Czech Republic } & \multicolumn{4}{|c|}{ Slovak Republic } \\
\hline HEALTH & -2.1518 & 0.2297 & -2.7066 & 0.0111 & -2.2946 & 0.4081 & -3.3308 & 0.0034 \\
\hline LIFEEXP & 4.5525 & 0.9999 & -5.5616 & 0.0008 & 4.5817 & 0.9999 & -4.0377 & 0.0482 \\
\hline REFUG & 3.0992 & 0.9980 & -3.8245 & 0.0010 & 0.7579 & 0.8651 & -4.7274 & 0.0038 \\
\hline UNEMPL & -2.9753 & 0.1745 & -3.7531 & 0.0013 & -2.0816 & 0.2536 & -2.2105 & 0.0310 \\
\hline NGO & 1.5058 & 0.9594 & -2.1858 & 0.0326 & 0.0996 & 0.6970 & -4.0406 & 0.0114 \\
\hline GDP & 2.1808 & 0.9884 & -5.0393 & 0.0001 & -2.2382 & 0.4358 & -3.7426 & 0.0205 \\
\hline AGE & 4.5356 & 1.0000 & -2.5895 & 0.0150 & 1.1061 & 0.9948 & -1.9989 & 0.0476 \\
\hline EDUC & 3.9083 & 0.9996 & -4.5962 & 0.0047 & -3.1010 & 0.1434 & -3.5927 & 0.0223 \\
\hline HEALTH & -3.0748 & 0.0585 & -2.7225 & 0.0107 & -2.7799 & 0.2325 & -3.0313 & 0.0059 \\
\hline LIFEEXP & 6.0194 & 1.0000 & -7.6935 & 0.0001 & 6.3682 & 1.0000 & -3.1500 & 0.0475 \\
\hline REFUG & -1.1928 & 0.8708 & -2.1135 & 0.0377 & -1.9350 & 0.3079 & -3.0436 & 0.0057 \\
\hline
\end{tabular}

Source: own calculations

Table 3

Engle-Granger Test

\begin{tabular}{cccccccc}
\hline \multicolumn{2}{c}{ Czech Republic } & \multicolumn{2}{c}{ Slovak Republic } & \multicolumn{2}{c}{ Hungary } & \multicolumn{2}{c}{ Poland } \\
\hline$t_{A D F}$ & Prob. & $t_{A D F}$ & Prob. & $t_{A D F}$ & Prob. & $t_{A D F}$ \\
\hline-4.0095 & 0.0007 & -6.9443 & 0.0000 & -17.7217 & 0.0001 & -6.7291 & 0.0000 \\
\hline
\end{tabular}

Source: own calculations

\section{Methods}

Authors used regression models of multidimensional time series to quantify relationships between variables. First, it is necessary to identify the level of integration of the time series. Table 2 gives results of Augmented DickeyFuller unit root test (Dickey \& Fuller, 1979) of the time series and of the first differences. The unit root test shows that all the time series, at the $5 \%$ significance level, are nonstationary, i. e. integrated I(1)

The essential assumption for analysing relationship between nonstationary time series of type $\mathrm{I}(1)$ is a cointegration of the time series. If the time series are not cointegrated, the regression is called "spurious regression". We differentiate the true regression from the spurious regression by analysing residuals of the static regression model.

$$
Y_{t}=\boldsymbol{\beta}^{\prime} \boldsymbol{X}_{t}+a_{t},
$$

If the residuals $a_{t}$ of this model are stationary I (0), then the time series are co-integrated. If the residuals are nonstationary I (1), there is a spurious regression.

The Engle-Granger co-integration test (Engle and Granger, 1987) in the table 3 shows that the time series are co-integrated at the $5 \%$ significance level.

As the model quantifies the one-way relationship between the variable $N G O$ and explanatory variables, the analysis of co-integration is processed either through simple multidimensional regression model $Y_{t}=\boldsymbol{\beta}^{\prime} \boldsymbol{X}_{t}+a_{t}$ (if the unsystematic component is not autocorrelated) or the Autoregressive Distributed Lag model (ADL) which has been often expressed as $\operatorname{ADL}(1,1)$

$$
\begin{aligned}
& Y_{t}=c+\alpha_{1} Y_{t-1}+\beta_{1} X_{t}+\beta_{2} X_{t-1}+a_{t}, \\
& \text { and Error Correction Model (ECM) } \\
& \Delta Y_{t}=c+\beta_{1} \Delta X_{t}+\chi\left(Y_{t-1}-\beta X_{t-1}\right)+a_{t},
\end{aligned}
$$

if there is an autocorrelation in the model (Hendry et al., 1984; Engle \& Granger, 1987). The ECM can distinguish between short-term and long-term relationships.

Annexed table 4 contains results of ADL model estimations for all countries including a diagnostic control. The diagnostic control used test of autocorrelation (Breusch and Godfrey, 1986), normality test (Jarque \& Bera, 1980) and heteroscedasticity test (Darnell, 1994) at the $5 \%$ significance level.

\section{Model Specification for the Czech Republic}

The short-term ADL model for the Czech Republic has following formula

$$
\begin{aligned}
& \widehat{N G O}_{t}=-4564.632-0.784 N G O_{t-1}+0.015 G D P_{t-1}- \\
& -69.295 A G E_{t}+78.500 A G E_{t-1}-18.360 E D U C_{t}- \\
& \text { - 0.134HEALT } T_{t}+60.064 L I F E E X P_{t}+6.725 R E F U G_{t}+ \\
& +11.288 U N E M P L_{t} .
\end{aligned}
$$

In the short-term period, the size of the non-profit sector serving households in the Czech Republic is directly proportional to the life expectancy at birth, number of refugees per hundred thousand inhabitants and unemployment rate in the same year $t$. There are inverse relationships between the size of non-profit sector serving households and the age structure, share of tertiary educated people and the government expenditures on health care per capita in the same year $t$. Moreover, there are delayed effects $(t-1)$ between the size of non-profit sector serving households, GDP and age structure.

Diagnostic control in the table 4 indicates that the unsystematic component of the model is not autocorrelated, is homoscedastic and normally distributed. Transformation of the ADL model to the ECM model provided following estimation: 
Jindrich Spicka, Marketa Arltova, Petr Boukal, Lubos Smrcka. Long-Term Determinants of the Size of the Non-Profit...

$$
\begin{aligned}
& \Delta \widehat{N G O}_{t}=-2558.64-69.29 \Delta A G E_{t}-18.36 \Delta E D U C_{t}- \\
& -0.13 \Delta H E A L T_{t}+60.06 \Delta L I F E E X P_{t}+6.73 \Delta R E F U G_{t}+ \\
& +11.29 \Delta U N E M P L_{t}-1.78\left[N G O_{t-1}-0.008 G D P_{t-1}-\right. \\
& -5.16 A G E_{t-1}+10.29 E D U C_{t-1}+0.08 H E A L T H_{t-1}- \\
& -33.67 L I F E E X P_{t-1}-3.769 R E F U G_{t-1}- \\
& \left.-6.327 U N E M P L_{t-1}\right] . \\
& \text { Transformation of the model to provide long-term }
\end{aligned}
$$
relationships has following final formula

$$
\begin{aligned}
N G O_{t} & =0.008 G D P_{t}+5.160 A G E_{t}-10.292 E D U C_{t}- \\
& -0.075 \text { HEALTH }_{t}+33.668 \text { LIFEEXP }_{t}+ \\
& +3.769 \text { REFUG }_{t}+6.327 \text { UNEMPL }_{t} .
\end{aligned}
$$

The long-term multiplicators show (ceteris paribus) that the increase of GDP per capita by 1 USD increases the size of non-profit sector serving households per capita by 0.008 USD. The increase of the old dependency ratio by 1 percentage point increases the size of the non-profit sector serving households per capita by 5.16 USD. When the share of tertiary-educated people increases by 1 percentage point, the size of the non-profit sector serving households per capita drops by 10.29 USD. The increase of the government health care expenditures per capita by 1 USD decreases the size of the non-profit sector serving households per capita by 0.075 USD. The life expectancy at birth goes in direct proportions with the size of the non-profit sector serving households - one year more means higher $N G O$ by 33.67 USD. When the number of refugees per hundred thousand of inhabitants increases by 1 person, the size of the nonprofit sector serving households per capita increases by 3.77 USD. Finally, higher unemployment rate by 1 percentage point increases the size of the non-profit sector serving households per capita by 6.33 USD. The results are discussed in the separate chapter.

\section{Model Specification for Slovakia}

The long-term determinants of the size of the non-profit sector serving households can be express by multivariate regression model. Diagnostic control of the model (table 4 in Annex) indicates that unsystematic component is not autocorrelated, is homoscedastic and is normally distributed. The model parameters are the same like in the ECM model with long-term indicators

$$
\begin{gathered}
\widehat{N G O}_{t}=9.466 E D U C_{t}+0.065 \mathrm{HEALT}_{t}+ \\
+0.584 \text { LIFEEXP }_{t}-5.799 \mathrm{REFUG}_{t} .
\end{gathered}
$$

The model indicates that (ceteris paribus), the increase of the share of tertiary-educated people by 1 percentage point increases the size of the non-profit sector serving households per capita by 9.47 USD. When the government health expenditures per capita move up by 1 USD, the size of the non-profit sector increases by 0.065 USD. The life expectancy index is positively related to the size of the nonprofit sector serving households - increase of life expectancy index by 1 year increases NGO by 0.584 USD. Finally, when the number of refugees per hundred thousand of inhabitants increases by 1 person, the size of the nonprofit sector serving households per capita decreases by 5.8 USD.

\section{Model Specification for Hungary}

The ADL model estimated for Hungary has following formula:

$$
\begin{aligned}
& \widehat{N G O}_{t}=-1.337 N G O_{t-1}-36.289 A G E_{t-1}+32.933 E D U C_{t-} \\
& \quad++0.207 H E A L T_{t}+9.522 \text { LIFEEXP }_{t}+ \\
& \quad+1.299 \text { REFUG }_{t}-8.889 U N E M P L_{t}
\end{aligned}
$$

From the short-term perspective, the final consumption of non-profits serving households positively depends on government health expenditure per capita, life expectancy at birth and number of refugees per hundred thousand inhabitants at the same year. Alternatively, the final consumption of non-profits serving households negatively depends on the unemployment rate in the same year. There are also delayed relationships. The size of nonprofits serving households positively depends on the share of people with tertiary education in the previous year; it negatively depends on the age structure and the final consumption of non-profits serving households in the previous year.

The diagnostic control of the model (table 4) indicates that unsystematic component of the model is not autocorrelated, is homoscedastic and is normally distributed.

Transformation of the ADL model to ECM model enables to get long-term relationships:

$$
\begin{aligned}
& \Delta \widehat{N G O}_{t}=0.207 \Delta H E A L T_{t}+9.522 \Delta \text { LIFEEXP }_{t}+ \\
& \quad+1.299 \Delta R E F U G_{t}-8.889 \Delta \text { UNEMPL }_{t}- \\
& \quad-2.337\left[N G O_{t-1}+15.529 A G E_{t-1}-\right. \\
& \quad-14.093 E D U C_{t-1}-0.089 H E A L T H_{t-1}- \\
& \quad-4.075 \text { LIFEEXP }_{t-1}-0.556 R E F U G_{t-1}+ \\
& \left.+3.804 \text { NEMPL }_{t-1}\right]
\end{aligned}
$$

thus, the long-term relationship can be expressed as $N G O_{t}=-15.529 A G E_{t}+14.093 E D U C_{t}+$ $+0.089 \mathrm{HEALTH}_{t}+4.075 \mathrm{LIFEEXP}_{t}+$ +0.556 REFUG $_{t}-3.804 U N E M P L_{t}$.

Under ceteris paribus assumption, the model indicates that an increase of the old dependency ratio by one percentage point decreases the size of non-profits serving households by 15.53 USD. Increase of the share of tertiaryeducated people by 1 percentage point increases the size of the non-profit sector serving households per capita by 14.09 USD. When the government health expenditures per capita move up by 1 USD, the size of the non-profit sector increases by 0.09 USD. The life expectancy index is positively related to the size of the non-profit sector serving households - increase of life expectancy index by 1 year increases NGO by 4.075 USD. Finally, when the number of refugees per hundred thousand of inhabitants increases by 1 person, the size of the non-profit sector serving households per capita increases by 0.556 USD. When the unemployment rate moves up by one percentage point, the final consumption of non-profits serving households drops by 3.8 USD.

\section{Model Specification for Poland}

The ADL model was estimated in the following form $\widehat{N G O}_{t}=-19.894 A G E_{t}+4.512 E D U C_{t-1}+$ +5.393 LIFEEXP $_{t}+1.265 R E F U G_{t}+12.249 D_{t}$.

In the short-term, there is only one lag. The size of the non-profit sector serving households positively depends on the share of tertiary-educated people in the country in the previous year. In the same year, there are positive relationships between NGO and life expectancy and the number of refugees per hundred thousand inhabitants. On the 
contrary, the NGO is negatively associated with the age structure in the country. Authors added the dummy variable $D$ (where $2010=1$ ) to remove the structural break in the model.

The diagnostic control of the model (table 3) indicates that unsystematic component of the model is not autocorrelated, is homoscedastic and is normally distributed.

After transformation of the model, the ECM can be written as:

$$
\begin{aligned}
\Delta \widehat{N G O}_{t} & =-19.894 \Delta A G E_{t}+5.393 \Delta \text { LIFEEXP }_{t}+ \\
& +1.265 \Delta R E F U G_{t}+12.249 D_{t}- \\
& -\left[N G O_{t-1}+19.894 A G E_{t-1}-4.512 E D U C_{t-1}-\right. \\
& \left.-5.393 L I F E E X P_{t-1}-1.265 R E F U G_{t-1}\right] .
\end{aligned}
$$

Finally, the long-term relationships can be expressed as follows.

$$
\begin{gathered}
N G O_{t}=-19.894 A G E_{t}+4.512 E D U C_{t}+ \\
+5.393 \text { LIFEEXP }_{t}+1.265 R E F U G_{t}
\end{gathered}
$$

The model indicates (ceteris paribus) that an increase of the old dependency ratio by one percentage point decreases the final consumption of the non-profit sector serving households by 19.89 USD. Other three variables have positive relationship with the size of the non-profit sector. Increase of the share of tertiary-educated people by 1 percentage point enables to move up the size of the non-profit sector serving households per capita by 4.51 USD. The life expectancy index is positively related to the size of the nonprofit sector serving households - increase of life expectancy index by 1 year increases NGO by 5.39 USD. Finally, when the number of refugees per hundred thousand of inhabitants increases by 1 person, the size of the non-profit sector serving households per capita increases by 1.265 USD.

\section{Discussion \\ GDP per Capita}

The Czech Republic is the only country from the Visegrad Group where the size of the non-profit sector serving households per capita depends on GDP per capita. In other countries, GDP is not significant determinant of the relative final consumption of non-profits. The reason for it could be the fact that all Visegrad countries except the Czech Republic have implemented tax assignation scheme. It means that the taxpayer of physical persons' income tax can decide which NGO receives maximum of $2 \%$ of the paid tax. Unlike the system of government subsidies, public finances collected by the state are not distributed after parliamentary budget approval, but by the decision of individual taxpayers. Moreover, the tax assignation scheme requires more bureaucracy and non-profit organization must be more marketing-oriented towards donors. In the Czech Republic, there isn't any tax assignation scheme. Physical persons and legal entities can deduct the value of the donation from the tax base.

In Hungary, there is a problem with relatively low disposable income of inhabitants in the investigated period. There has been quite high household debt ratio due to the support of mortgages under the time of prime minister Gyurcsany (2007-2008). Figure 1 shows the Gross debt-toincome ratio of households in the Visegrad countries. Hungarian households had the highest debt-to-income ratio till 2011. However, they have sharply reduced it since 2012.
Because the investigated period in the model is 2000-2014, the specific household debt ratio affected the relationship between country's wealth and the size of the non-profit sector serving households in Hungary.

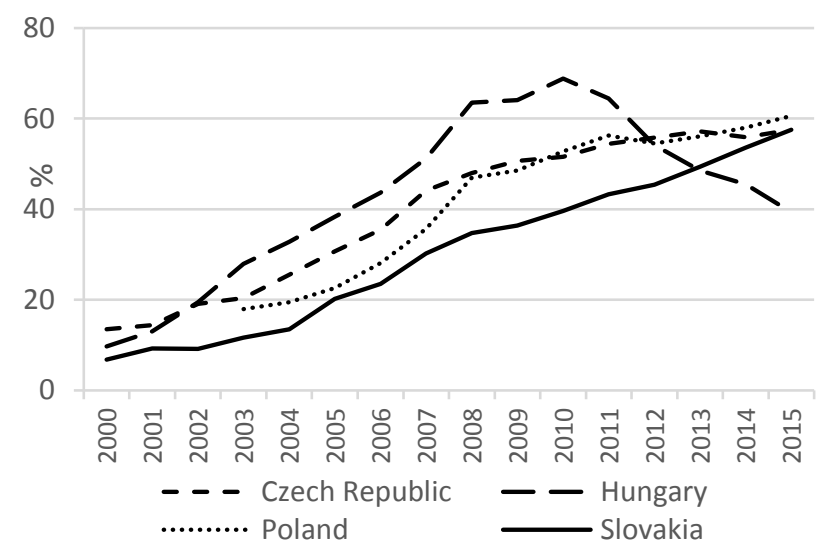

Figure 1. Gross debt-to-income ratio of households in the Visegrad Group

Source: Eurostat

\section{The Level of Education}

The level of education is the second supply-side determinant of the non-profit sustainability. The primary assumption was that the higher the education level of the population, the greater the altruistic behavior of the society as well as a dimension of non-profit organizations in the country. A positive relationship between the size of nonprofits serving households and the share of tertiary-educated people in the country was established in Slovakia, Hungary and Poland. So, this factor can be established as supply-side determinant of the non-profit sector in three of four Visegrad countries. Alternatively, there is a negative relationship in the Czech Republic. Explanation would require more in-depth sociological survey. However, according to a hypothesis that draws on demographicstructural theory, the acceleration in international NGO numbers during the last 50 years was caused by the post-war baby boom and a crisis in the credential system (Turner, 2010). After testing the hypothesis according to which it was the growing supply of credentialed professionals, rather than the greater demand for their services, that has been the proximate mechanism for the surge in those organisations, Turner concludes that the growth of NGOs was due to the "cyclical demographic-structural processes which have increased intraelite competition over the last half-century. Having in mind that the share of graduates of tertiary education has increased manifold in these countries after the transitions (in Poland, this increase was more than 5-fold), it is highly possible that it was not the over-supply of qualified individuals (unable to find job in the other sectors) which triggered the growth of NGOs, rather than these individuals' alleged altruistic inclinations.

\section{The Old-Age dependency Ratio and the Life Expectancy}

The age structure of population measured by old-age dependency ratio $(\%)$ has been long-term significant determinant of the size of the non-profit sector serving households in three of four Visegrad countries (Czech 
Republic, Hungary, Poland). However, there is the positive relationship in the Czech Republic but negative in Hungary and Poland, caused by different social care systems between the countries. The positive relationship between age structure and the size of the non-profit sector serving households in the Czech Republic relates to the relatively important role of non-profit social care for the elderly which has been in the spotlight since 2000. Services for the elderly are provided within the medical and social sectors. The Czech system of social care for the elderly is based on institutional care (Sowa, 2010), which is partly provided within the health care system (in hospital departments or aftercare, rehabilitation and long-term care departments) and partly within the social services system (in retirement homes). Moreover, there is the highest regression coefficient between NGO and LIFFEXP (33.668) in the Czech Republic. Alongside, the Czech Republic has the highest average life expectancy at birth from the Visegrad Group (76.63). It means that the non-profit social and health care of the elderly in the Czech Republic flexibly responds to the life expectancy and age structure of the population.

In Hungary and Poland, the higher old dependency ratio, the lower financial consumption of non-profits serving households per capita. In the field of social protection, Poland belongs to the EU group of countries with a familybased and private welfare model. The development of formalized, non-family long-term care is in the initial stages and is similar in both sectors: medical and social (Golinowska, 2010). Institutional care provided by nursing and care institutions are designed for the elderly whose daily living activities are limited, and who do not have families or need institutional care for other reasons, such as poverty. So, the relatively marginal role of institutional sector and NGOs in the social care for the elderly is a reason for negative relationship between old dependency ratio and relative size of the non-profits serving households.

Hungarian system of social care is totally different, somewhere between the Czech and Polish system. "The Hungarian long-term care system still bears the marks of the central planning that was in effect in the country between 1950 and 1990. The organisational logic of the planner dictates centralisation (for it is easier to control fewer institutions) - a preference for institutionalised care over managing personal networks (such as home-based care) and a kind of organisational blindness that does not notice needs beyond its sphere of operations. The consequence, as in other fields of activities, is a dual structure: a centralised system of institutions and a wide range of household activities by which people adjust to the situation" (Czibere $\& \mathrm{Gal}, 2010)$. A negative relationship between the $A G E$ and $N G O$ could be caused by limited public resources and inefficient employment of these resources. It indicates a higher use of private home care for the elderly rather than institutional care.

In Slovakia, the old-age dependency ratio is not significant determinant of the size of the non-profit sector serving households. Long-term care is interpreted in terms of meeting two needs - for social care and medical care provided by separate social and medical care services (Radvansky and Palenik, 2010). While health care is legally and formally provided by the state, social care, including care of elderly, is partly provided by the state, regions, charitable and private institutions. A strong distinction between state health care and more diversified social care could be a reason for difficult-to-detect dependence between old dependency ratio and the size of the non-profit sector serving households. The fact that the final consumption of non-profit sector serving households does not respond to the age structure points to the rigid system of social care in Slovakia. This conclusion is supported by the lowest regression coefficient between $N G O$ and life expectancy at birth in Slovakia (0.584). However, Slovakian long-term care services are currently undergoing a transitional phase.

\section{The Government Health Expenditure Per Capita}

The higher government health expenditures per capita negatively affect the size of the non-profits serving households in the Czech Republic. There is an obvious competitiveness between social and health care system which is not as separated like in Slovakia (legal and formal separation) or has different character than in Hungary (home care, meal provision, daytime care and residential care) and Poland (private home care).

The government failure theory was established only in the Czech Republic. In Slovakia and Hungary, the government failure theory has not been confirmed. While growing government expenditures on health care, the final consumption expenditure of non-profit institutions serving households is growing on a long-term basis, which is supported by critics of the government failure theory (Matsunaga et al., 2010; Salamon \& Toepler, 2015). However, this can be explained by the complementarity of activities carried out by the government and by non-profit institutions, where services of these sectors do not compete, but rather support and complement each other. In Poland, the government health expenditures are not significant determinant of the size of non-profit sector serving households because there has been a growth of for-profit institutions providing such services. Over the last five years, there has been a $25 \%$ increase of elderly people using those services, i.e. not relying on their relatives for care.

\section{The Number of Refugees Per Hundred Thousand Inhabitants}

The question of refugees has been recently more discussed. There is an evidence that local government capacity moderated the negative impact of immigration on public service providers (Andrews et al., 2013). The highest relative number of refugees in the Visegrad Group is typical for Hungary, which is a part of the Balkan path for refugees from Islamic countries, Poland (refugees from the East, especially Ukraine) and the Czech Republic. In the countries, there is a positive relationship between relative number of refugees and the size of the non-profit sector. Non-profit organizations help governmental sector to cope with increasing number of refugees in need coming from war regions. On the contrary, there is significantly lowest relative number of refugees in Slovakia. Moreover, there is a negative relationship between the relative number of 
refugees and the size of the non-profit sector. Slovakia has relatively distinctive and strongly restrained attitude to refugees.

\section{Unemployment Rate}

The unemployment rate is significant determinant of the size of the non-profit sector serving households in the Czech Republic (positive relationship) and Hungary (negative relationship). There is no relationship in the Slovak Republic and Poland since the unemployment assistance has not been a purpose of the non-profits but state offers a basic care. In the Czech Republic, there is a public social system for support of unemployed people. The non-profit sector offers alternative help in the form of social non-profit organizations which focus on various socially vulnerable groups (e.g. associations for the disables, single mothers, minorities, gender issues). Moreover, there are social companies which offer job for needy people. All these nonprofit organizations contribute to mitigation negative consequences of unemployment. The negative relationship in Hungary indicates that an increase in unemployment benefits cuts resources for the support of non-profit organizations because of quite high level of centralisation of health and social care in Hungary.

\section{Conclusions}

The four models of long-term determinants of the nonprofit sector size in the Visegrad Group indicate different conditions for the non-profit organizations serving households in each country. Most factors result from policy framework and development in the country. GDP per capita is the significant determinant of the non-profit sector in the country with no tax assignation. This conclusion supports the critical view on tax assignation as an alternative way how to transfer money to the non-profit sector. In fact, tax assignation does not bring new money for the non-profit organizations. It is just a new way of redistribution with a lot of bureaucracy and increased demands on marketing campaign for the non-profits.

The different systems of care for the elderly have an impact on the determinants of the size of the non-profit sector serving households. The age structure and the life expectancy show that the non-profit organizations serving households in the Czech Republic can flexibly respond to increasing age structure and life expectation index. Alternatively, the age structure negatively affects the size of the non-profit sector serving households in the country with either marginal institutional social care for the elderly (Poland with family-based welfare model) or in the country with prevailing centralized system (Hungary).

The government failure theory was established only in the Czech Republic where is an obvious competitiveness between social and health care system. The old dependency ratio and government health expenditures have inverse relationship against the size of the non-profit sector serving households. Policy makers should make more intensive steps towards integrating social and health care.

Live expectancy at birth positively affects the size of the non-profit sector serving households in all countries of the Visegrad Group. However, a level of regression coefficient indicates different flexibility of the non-profit social care between the countries. The non-profit social care in the Czech Republic flexibly responds to the life expectancy (and age structure) of the population. In other countries, the non-profit social and health care system for the elderly is less flexible (and should be restructured) or marginal.

The immigration has been more important policy issue recently. In the most Visegrad countries, non-profit organizations help governmental sector to cope with increasing number of refugees in need coming from war regions. It is an important finding supporting interdependence theory and chance for the future since there has been a sharp increase of immigration from war regions beyond the investigated period (i.e. since 2015).

The scientific contribution of the paper is that it shows that researchers cannot generally accept or question government failure theory and interdependence theory. Effects are country-specific because they depend on the organization of non-profit sector, centralization and flexibility of governmental social care and health care system in each country. Results also point out importance of historical development of society and traditions affecting current system of non-profit sector.

Further research should follow up a structure of activities of the non-profit sector in each country to reveal structural determinants of the size of the non-profit sector serving households.

\section{Annex}

Table 4

ADL Models and Diagnostic Tests

\begin{tabular}{|c|c|c|c|c|c|c|c|c|c|c|c|c|c|c|c|c|}
\hline \multirow[b]{2}{*}{ Variable } & \multicolumn{4}{|c|}{ Czech Republic } & \multicolumn{4}{|c|}{ Slovak Republic } & \multicolumn{4}{|c|}{ Hungary } & \multicolumn{4}{|c|}{ Poland } \\
\hline & Coeff. & S.E. & t-Stat. & Prob. & Coeff. & S.E. & t-Stat. & Prob. & Coeff. & S.E. & t-Stat. & Prob. & Coeff. & S.E. & $\mathrm{t}$-Stat. & Prob. \\
\hline $\mathrm{C}$ & $\begin{array}{c}- \\
4564.63\end{array}$ & 448.622 & 10.1748 & 0.0005 & & & & & & & & & & & & \\
\hline $\mathrm{NNO}(-1)$ & -0.7840 & 0.1849 & -4.2413 & 0.0132 & & & & & -1.3369 & 0.3572 & -3.7427 & 0.0072 & & & & \\
\hline GDP(-1) & 0.0149 & 0.0031 & 4.8690 & 0.0082 & & & & & & & & & & & & \\
\hline AGE & $69 . \overline{2} 945$ & 14.2542 & -4.8614 & 0.0083 & & & & & & & & & 19.8943 & 3.3449 & -5.9477 & 0.0002 \\
\hline $\operatorname{AGE}(-1)$ & 78.5001 & 14.3725 & 5.4618 & 0.0055 & & & & & -36.2898 & 13.4744 & -2.6932 & 0.0309 & & & & \\
\hline EDUC & $\begin{array}{c}- \\
18.3601\end{array}$ & 3.0140 & -6.0916 & 0.0037 & 9.4661 & 2.9042 & 3.2595 & 0.0076 & & & & & & & & \\
\hline EDUC(-1) & & & & & & & & & 32.9329 & 6.8114 & 4.8350 & 0.0019 & 4.5121 & 1.1382 & 3.9642 & 0.0033 \\
\hline HEALT & -0.1343 & 0.0312 & -4.3042 & 0.0126 & 0.0645 & 0.0243 & 2.6543 & 0.0291 & 0.2070 & 0.0362 & 5.7181 & 0.0007 & & & & \\
\hline LIFEEXP & 60.0637 & 6.1603 & 9.7502 & 0.0006 & 0.5837 & 0.1464 & 3.9878 & 0.0021 & 9.5216 & 3.5136 & 2.7099 & 0.0302 & 5.3935 & 0.6682 & 8.0716 & 0.0000 \\
\hline REFUG & 6.7241 & 0.8057 & 8.3454 & 0.0011 & -5.7998 & 1.1177 & -5.1889 & 0.0003 & 1.2986 & 0.3395 & 3.8248 & 0.0065 & 1.2657 & 0.3156 & 4.0100 & 0.0031 \\
\hline UNEMPL & 11.2875 & 1.9410 & 5.8152 & 0.0044 & & & & & -8.8894 & 2.1063 & -4.2204 & 0.0039 & & & & \\
\hline
\end{tabular}


Jindrich Spicka, Marketa Arltova, Petr Boukal, Lubos Smrcka. Long-Term Determinants of the Size of the Non-Profit...

\begin{tabular}{|c|c|c|c|c|c|c|c|c|c|c|c|}
\hline $\mathrm{D}$ & & & & & & & & 12.2491 & 3.8754 & 3.1607 & 0.0115 \\
\hline$R^{2}$ & 0.9973 & & & 0.9721 & & 0.9716 & & 0.9958 & & & \\
\hline$R_{a d j}^{2}$ & 0.9913 & & & 0.9645 & & 0.9473 & & 0.9939 & & & \\
\hline \multicolumn{2}{|c|}{ Diagnostic Tests } & Stat. & Prob. & Stat. & Prob. & Stat. & Prob. & & Stat. & Prob. & \\
\hline \multicolumn{2}{|c|}{$\begin{array}{l}\text { Breusch-Godfrey Serial } \\
\text { Corr. LM Test }\end{array}$} & 12.3532 & 0.0749 & 0.7389 & 0.5045 & 3.0355 & 0.1371 & & 2.6117 & 0.2709 & \\
\hline \multicolumn{2}{|c|}{$\begin{array}{l}\text { Heteroskedasticity Test: } \\
\text { ARCH }\end{array}$} & 0.3152 & 0.5745 & 0.3966 & 0.5289 & 0.0230 & 0.8794 & & 0.6606 & 0.4163 & \\
\hline \multicolumn{2}{|c|}{ Normality Jarque-Bera Test } & 0.0887 & 0.9566 & 1.6643 & 0.4351 & 6.5762 & 0.0833 & & 1.9987 & 0.3681 & \\
\hline
\end{tabular}

Source: own calculations

\section{References}

Andrews, R., Boyne, G., O'Toole, L., Meier, K., \& Walker, R. (2013). Managing migration? EU enlargement, local government capacity and performance in England. Public Administration, 91(1), 174-194. https://doi.org/10.1111/j.1 467-9299.2012.02043.x

Bae, K. B., \& Sohn, H. (2017). Factors contributing to the size of nonprofit sector: tests of government failure, interdependence, and social capital theory. Voluntas, Online First (16 August 2017), https://doi.org/10.1007/s11266017-9888-3.

Breusch, T. S., \& Godfrey, L. G. (1986). Data transformation tests. Economic Journal, 96, 47-58. https://doi.org/10.2 307/2232969

Czibere, K., \& Gal, R. I. (2010). The long-term care system for the elderly in Hungary. ENEPRI research report No. 79/June 2010", available at: http://www.ancienlongtermcare.eu/sites/default/files/ENEPRI\%20RR\%20No\%2079\%20Hungary.pdf (accessed 23 February 2017).

Darnell, A. C. (1994). A dictionary of econometrics, Elgar, Aldershot.

Dickey, D. A., \& Fuller, W. A. (1979).: Distribution of the estimators for autoregressive time-series with a unit root. Journal of the American Statistical Association, 74(366), 427-431. https://doi.org/10.2307/2286348

Engle, R. F., \& Granger, C. W. (1987). Cointegration and error correction - representation, estimation, and testing. Econometrica, 55(2), 251-276. https://doi.org/10.2307/1913236

European Commission (2013). European systems of accounts 2010. Available at: http://ec.europa.eu/eurostat/web/productsmanuals-and-guidelines/-/KS-02-13-269.

Gazley, B. (2010). Linking collaborative capacity to performance measurement in government-nonprofit partnerships. Nonprofit and Voluntary Sector Quarterly, 39(4), 653-673. https://doi.org/10.1177/0899764009360823

Gil-Lacruz, A. I., \& Marcuello, C. (2013). Voluntary work in Europe: comparative analysis among countries and welfare systems". Social Indicators Research, 114(2), 371-382.

Golinowska, S. (2010). The long-term care system for the elderly in Poland. ENEPRI research report No. 83/June 2010", available at: http://www.ancien-longtermcare.eu/sites/default/files/ENEPRI\%20RR\%20No\%2083\%20(ANCIEN \%20 -\%20Poland).pdf (accessed 23 February 2017).

Gronbjerg, K. A., \& Paarlberg, L. (2001). Community variations in the size and scope of the nonprofit sector: Theory and preliminary findings. Nonprofit and Voluntary Sector Quarterly, 30(4), 684-706. https://doi.org/10.1177/08 99764001304004

Hendry, D., Pagan, A., Sargan, J. (1984). Dynamic specifications. In Griliches, Z. and Intriligator, M. (Eds.), Handbook of Econometrics, II, North Holland, Chap. 18. https://doi.org/10.1016/S1573-4412(84)02010-9

Jarque, C. M., \& Bera, A. K. (1980). Efficient tests for normality, homoscedasticity and serial independence of regression residuals. Economics Letters 6 (3), 255-259. https://doi.org/10.1016/0165-1765(80)90024-5

Lecy, J. D., \& Van Slyke, D. M. (2013). Nonprofit sector growth and density: testing theories of government support. Journal of Public Administration Research and Theory, 23(1), 189-214. https://doi.org/10.1093/jopart/mus010

Liu, G. (2017). Government decentralization and the size of the nonprofit sector: revisiting the government failure theory. The American Review of Public Administration, 47(6), 619-633. https://doi.org/10.1177/0275074016631643

Luksetich, W. (2008): Government funding and nonprofit organizations. Nonprofit and Voluntary Sector Quarterly 37(3). https://doi.org/10.1177/0899764007310415

Matsunaga, Y., Yamauchi, N., \& Okuyama, N. (2010). What determines the size of the nonprofit sector? A cross-country analysis of the government failure theory. Voluntas, 21(2), 180-201. https://doi.org/10.1007/s11266-010-9125-9

Mccarthy, M., \& Knabe, A. (2012). Civil society and public health research in the European Union new member states. Scandinavian Journal of Public Health, 40(3), 253-259. https://doi.org/10.1177/1403494812443601

O'regan, K., \& Oster, S. (2002). Does government funding alter nonprofit governance? Evidence from New York city nonprofit contractors", Journal of Policy Analysis and Management, 21(3), 359-379. https://doi.org/10.10 02/pam. 10050 
Pevcin, P. (2012). Analysis of cross-country differences in the non-profit sector size. Prague Economic Papers 21(2), pp. 186-204. https://doi.org/10.18267/j.pep.418

Potucek, M. (2000). The uneasy birth of czech civil society. Voluntas, 11(2), 107-121. https://doi.org/10.1023/A: 1008915807784

Pryor, F. L. (2012). Determinants of the size of the nonprofit sector. The European Journal of Comparative Economics, 9(3), 337-348.

Radvansky, M., \& Palenik, V. (2010). The long-term care system for the elderly in Slovakia. ENEPRI research report No. 86/June 2010", available at: http://www.ancienlongtermcare.eu/sites/default/files/ENEPRI\%20_ANCIEN_\%20RR\%20No\%2086\%20Slovakia\%20-\%20Final.pdf (accessed 23 February 2017).

Salamon, L. M., \& Toepler, S. (2015). Government-nonprofit cooperation: Anomaly or necessity?. Voluntas, 26(6), 21552177. https://doi.org/10.1007/s11266-015-9651-6

Schmid, H. (2004). The role of nonprofit human service organizations in providing social services: A prefatory essay. Administration in Social Work 28 (3/4), 1-21. https://doi.org/10.1300/J147v28n03_01

Sowa, A. (2010). The long-term care system for the elderly in the Czech Republic. ENEPRI research report No. 72/May 2010. Available at: http://www.ancienlongtermcare.eu/sites/default/files/ENEPRI\%20RR\%20No\%2072\%20ANCIEN\%20Czech\%20Republic.pdf (accessed 23 February 2017).

Strecansky, B. (2012). The situation of the third sector in Slovakia, the impacts of crisis, trends, mainstreams and challenges. Available at: http://www.cpf.sk/files/files/Pages\%20from\%20Civil_Szemle_2012_3.pdf.

Struyk, R. J. (2002). Nonprofit organizations as contracted local social service providers in eastern Europe and the commonwealth of independent states. Public Administration and Development 22(5), $429-437$. https://doi.org/10.1002/pad.243

Toepler, S., \& Salamon, L. M. (2003). NGO development in Central and Eastern Europe: An empirical overview. East European Quarterly, 37(3), 365-378.

Turner, E A. L. (2010). Why has the number of international non-governmental organizations exploded since 1960 ? Cliodynamics, 1(1), 81-91.

Valentinov, V. (2008). The Economics of nonprofit organization: In search of an integrative theory. Journal of Economic Issues, 42(3), 745-761. https://doi.org/10.1080/00213624.2008.11507177

Valentinov, V., \& Vacekova, G. (2015). Sustainability of rural nonprofit organizations: Czech Republic and beyond. Sustainability, 7(8), 9890-9906. https://doi.org/10.3390/su7089890

Van Puyvelde, S., \& Brown, W.A. (2016). Determinants of nonprofit sector density: A stakeholder approach. Voluntas, 27(3), 1045-1063. https://doi.org/10.1007/s11266-015-9656-1

WB (2016). World Bank open data. World Bank. Retrieved from <http://databank.worldbank.org/data/home.aspx>

Weinblatt, J. (1992). Do government transfers crowd out private transfers to nonprofit organizations - the Israeli experience. International Journal of Social Economics, 19(2), 60-66. https://doi.org/10.1108/EUM0000000000482

WHO (2016). Global Health Observatory (GHO) data. World Health Organization. Retrieved from <http://www.who.int/ gho/database/en/>

The article has been reviewed.

Received in October, 2017; accepted in December, 2017. 